\title{
The Degree to Which Students and Teachers Are Involved in Second- Level School Processes and Participation in Decision Making: An Irish Case Study
}

\author{
Dr Kathy Harrison ${ }^{\mathrm{a}}$, Dr Alison Taysum ${ }^{\mathrm{b}}$, Professor Gerry McNamara ${ }^{\mathrm{a}}$ \\ and Professor Joe O'Hara ${ }^{\text {a }}$ \\ ${ }^{a}$ School of Education Studies, Dublin City University, Dublin, Ireland; ${ }^{b}$ School of \\ Education, University of Leicester, Leicester, UK
}

\begin{abstract}
The Education Act (1998) is a key policy document in Irish education, emphasising the rights, roles and responsibilities of key stakeholders, including parents, teachers and pupils in schools. Since 1998 the Department of Education and Skills (DES) has stressed the need to introduce an increased role for teachers and pupils in decision- making. It is therefore timely to explore the response of teachers and students to such a collaborative school environment in a rural second-level school of approximately 600 students. Transition Year (TY) students (ages about 15 - 16) and their teachers were surveyed by questionnaire and interviewed. It finds that while the school is proactive in involving students and teachers in decision making, a source of social, personal and professional empowerment, experienced teachers, and students in particular, want a more substantial voice. For example, most students want more say. They want class discussions or a vote, not just Student Council (SC) representation, on important and not just trivial issues. They want involvement before decisions are taken, with more feedback. Overall, participation is considered important by all stakeholders.
\end{abstract}

Keywords: decision-making, participation, democratic, leadership, learning organisation, critical thinking 


\section{Introduction}

This article describes a case study in a second-level school with over 600 students in rural Ireland. It examines student (60) and teacher (26) involvement in school life, particularly the extent of their participation in decision-making processes. The research focuses on Transition Year (TY) (approximate age 15-16 years), uniquely a year free from assessments between lower secondary school and the Leaving Certificate programme (the final second-level assessment, leading into work or further or higher education). Students can pursue subjects related to community, enterprise, personal or social development. The Department of Education and Science (DES) (1994) advises 'curriculum content is a matter for selection ... by the individual school' and provides broad signposts, subject areas, encouraging consideration of local community interest and employment prospects. This flexibility permitted students to participate in this study without disrupting their formal curriculum.

This study, with the collaboration of students, teachers and school leadership, adds richness and depth to the body of knowledge on inclusive, more democratic education. The generated knowledge aims to inform policy and practice, and with the broad base of participants, increases the likelihood of improving standards of educational excellence. Thus, this research attempts to inform educational policy to enhance future education provision.

The research recognises that 'educational policy is a public good associated with human rights' (Taysum, 2013), agreeing with Irish government policy: a DES (2011: 3) stated objective is 'to enable learners to achieve their full potential and contribute to Ireland's economic, social and cultural development'. This outlook is 
educationally culturally responsive, nurturing all learners regardless of gender, creed, ethnicity or socio-economic background. The principles of Culturally Responsive Evaluation and Assessment (CREA), (2013) seek to 'increase the likelihood that social and educational policies and practices are more socially just (fair, equitable, [and] respectful of human dignity)': they guide this study, ensuring the research and any proposed changes are congruent with democracy and social justice.

This focus on social justice and democratic principles is a move away from total concentration on academic prowess to a more holistic education where skills of democracy are introduced and nurtured. Banks (1997: 1) argues that 'people are not born democrats. Consequently, an important goal of the schools in a democratic society is to help students acquire the knowledge, values, and skills needed to participate effectively in public communities'. Irish policy acknowledges that children need to develop their age-appropriate voice (National Children's Strategy, 2000). Broader recognition of this philosophy in an holistic educational context is highlighted by the United Nations (UN) (1948). Article 26.2 of the Universal Declaration of Human Rights states that 'education shall be directed to the full development of the human personality ...', a right written into international law in the International Covenant on Economic, Social and Cultural Rights as Article 13.1, signed by Ireland in 1973 and ratified in1989.

\section{Context - Teaching in Ireland}

It is widely accepted that the teacher's role includes the provision of a level, discrimination-free playing field for each learner so she/he can thrive. Bhreathnach (1995: 9) corroborates this, claiming 'students are entitled to the highest possible standard of teaching and to be facilitated in the attainment of the highest quality of 
learning'. Taylor (1998: 218) personalises this for the teacher, suggesting that 'in choosing to become a teacher you have acknowledged your own responsibility to meet the personal, social and intellectual needs of every pupil in your care, day upon day, year upon year'.

Overall, Irish teachers are perceived to enjoy public confidence. O'Donoghue and Harford (2010: 99) note that at graduation, Irish student teachers have progressed through the most competitive selection and training process in Europe. They observe that 'teaching in Ireland carries a high social status and teachers typically enjoy good levels of public support'. However, from a leadership perspective, teachers' motivation can be thwarted and they can experience isolation in attempts to contribute to education policy. Brown (2005: 398) points to a major reason for teacher frustration when she remarks,

over recent years many [teachers] have come to see themselves as powerless in the face of highly prescribed curricula, and they have little enthusiasm for creative developments that are unlikely to have an impact on 'official' ways of thinking.

The impact of this and the incumbent diminished motivation is reflected by McNamara and O'Hara (2008). Researching developing professionalism in education through self evaluation, they argue that many projects promising long term success 'have faded away when the impetus for them has been withdrawn' (p. 202), and 'lack of ongoing motivation seems to gradually erode early enthusiasm for reflection and self-study' (p. 203). Increased support, with the necessary resources, including time, training, and a non-threatening environment, was suggested as a way to ameliorate this situation. McLean (2003: 5) points out the primacy of influence on school life of 
motivation, suggesting 'teachers need to nurture their own self-motivation ... before they consider how they are going to motivate their students'.

Diminished motivation in teacher-led research is also observed by Sugrue (2009) who claims educational policy is not informed by such research. Reviewing all educational sectors, Sugrue highlights a possible reason for the dearth of teacher input into educational reform: published research in Ireland is predominantly small-scale, single authored, one-off papers, indicating a lack of both funding and an established research culture. He emphasises that, without large scale collaborative research and the commensurate funding, there can be no consistent research to inform educational policy and make substantial inputs into educational reform. However, Loughran (2006) also points to initial teacher education for the slow progress, suggesting student teachers find the area of research taxing. He states they need support in their efforts, and research should be included in all initial teacher education. It could be added here that this challenge is not solely confined to new teachers. Unless given skills, time and encouragement, experienced teachers too may find research equally challenging. Teacher motivation can be positively impacted by empowerment, through participation in school processes as examined in this research. Moreover, such experience more positively impacts teacher and learner motivation in the areas of social justice and democratic processes. See for example Zhang (2011) for the impact of democratisation in China and its effects on educational institution leadership, and French (2007) for a summary of the benefits afforded young children by their participation in education. These are reflective of democracy in education as outlined by the European Democratic Education Community (EUDEC, 2015), which claims democratic learning comes through nurturing natural curiosity, resulting in 'motivated, innovative, lifelong learners'. This philosophy is practiced in Sands 
School (2015) in the U.K., one of 'about 100 schools around the world [who] describe themselves as "free" or "democratic"' (Sliwka, 2008). Ofsted (2013) reports:

The school's leadership and management arrangements, in which all pupils and staff are actively involved, have a good impact on quality of teaching and pupils' achievements. They provide the basis of a flourishing school community

One reason so few schools practice democracy could be traditional hierarchical management and leadership styles, a natural barrier to the adoption of such a democratic model.

\section{Changing Culture}

The learner-teacher relationship is paramount in learning. This is illustrated across the educational spectrum by such as Harley et al. (2000) and Hanushek et al. (1998). The former examined teachers' roles in a newly-integrated South Africa. The latter carried out a large scale study into the teacher's role and the effect of teachers' level of qualification and experience (an implied measure of quality). They found, from over 3000 Texan schools, the single most significant factor affecting student achievement is teacher quality. In Ireland Smyth (1999: 54) maintains 'the nature of relationships between teachers and pupils in a school has a significant effect on pupil performance'.

A move towards a more culturally sensitive, holistic relationship between teacher and learner is apparent in the work of Fox (1993: 144) who cautions against ignoring the 'social side' of learning, and Harley et al. (2000: 299) who, despite not ranking pastoral care highly, note that in a school which 'projected a strong sense of cohesion and community, the roles of "Mediator of Learning" and "Pastoral Care" were 
accorded priority’.

This broader approach to the learner-teacher relationship implies a natural inclusion of learner participation in more than just learning. It leads toward student involvement in other school processes, a development Fox sees as necessary to engage learners fully and optimise their learning. It also impacts more than just pupil performance, helping to facilitate the development of metacognitive skills: skills which can help offset automatic, 'low-effort thinking'. Aronson et al. (2005: 59) describe this as 'unconscious, unintentional, involuntary, and effortless', arguing this is how individuals spend the majority of time operating. A good relationship can foster development of management of how one thinks, 'controlled thinking' (p. 82), which can lead to decisions based on reasoned logic rather than habit, or some other unconscious influence. It makes for common sense, according to Bowne (1908: 27) 'something; which is there for all and which can be depended upon'. Thus, the learner can develop skills which can add to the development of her/his community, employing what Paul and Elder (2006: xxiii) describe as 'self-directed, selfdisciplined, self-monitored, and self-corrective thinking', the capacity to evaluate one's own reasoning, one of the rudimentary principles of critical thinking.

However, to fully realise these benefits, focus has to transcend Ireland's prevailing culture, where teacher-learner relationships are bound by curriculum in pursuit of examination grades (Submission to the National Strategy for Higher Education, 2009). To enable this there must be more student and teacher involvement in school processes and decision-making. This will provide practice and experience, and build individual and social capacity with greater student engagement and learning. Resulting in transparency, shared responsibility and ownership of school processes by 
both students and teachers, this will foster joint development. These form the basis of a Learning Organisation, depicted by Longworth (1999: 215) as one which ‘... encourages, all its people in all its functions to fulfil their human potential ... by putting the emphasis on "learning" and planning its education and training activities accordingly' .

Described by Senge (2000) as a vision, a Learning Organisation is one in which:

- all individuals are engaged

- the individual strives to reach personal goals

- personal, collective and organisation goals are in alignment

- the individuals care - convinced they make a difference

Such a learning environment can sustain staff, teacher and student motivation. Founded on equality, inclusion, collaboration and trust it embraces a whole school approach indicative of a community of practice as described by Lave and Wenger (1991), one built on shared knowledge, skills and insight. Information is generated and shared freely among participants, specifically learners. This sharing of knowledge and experience again fosters engagement, deeper learning and personal development, an interdependent approach adding value to those involved. The individual and collective skills and knowledge gained act as resources in further development of both school and wider community. Hebert (2006: 5) resonates these concepts describing how, as a prospective principal, her success as a leader would develop from her 'ability to create and sustain a sense of community ...'. She recounts that her approach to leadership was based on listening to all views and taking a collaborative approach rather than 'the expected "principal as leader and teachers as 
followers" dynamics' (p. 44). She also extends to students both the value of listening to all views, and the cultivation of leadership skills, which can help them, both in school and later, throughout their lives. These models share commonality with a collegial approach, which Bush (2003) argues is prevalent in higher and primary education, but slower in uptake in secondary schools, which he attributes to the established tradition of a hierarchical management style. It is 'decision-making as a participative process with all members of the institution having an equal opportunity to influence policy and action' (Bush, 2003: 74), which describes its strength and the main obstacle to its uptake, the diffusion of responsibility.

\section{The Research}

\section{Methodologies}

A case study approach was adopted because it was an in-depth examination of processes in a single school. Flexible, this approach permitted exploration, discovery and focusing on interesting and productive points, rather than trying to predict outcomes and working to a fixed plan.

To maintain objectivity an Interpretive Phenomenological Approach (IPA) (Husserl, 1931) was used throughout data gathering and analysis. This allowed bracketing of the researcher's own views and biases whilst exploring the meaning of the individual's experience as participants were led through a reflective process to elicit their interpretation. Individual concepts were then identified from participants' stories using constant comparison analysis, through an iterative process of checking and cataloguing by meaning. The final theory was allowed to 'emerge' from the data as described in Grounded Theory by Glaser and Strauss (1967).

Data were gathered from the viewpoints of teachers and students and drew on the 
combination of research methodologies, employing a number of collection tools. This methodological mix helped triangulate the findings of the study (Berg, 2004).

\section{This Study}

The study was carried out in a second-level rural school in the Irish midlands with students in TY ( $4^{\text {th }}$ year, about $15-16$ years) education and their teachers from the current or previous year. Teachers involved in the research are identified as experienced (with ten or more years teaching experience) and inexperienced (with less than ten years experience). There was a gender mix in students and teachers, with sixty students and twenty-six teachers participating in total.

As the research aim was investigating the experience of being involved in processes in school, both qualitative and quantitative methodologies were employed. Teachers and students were interviewed using a semi-structured approach that Fisher (2007: 159), suggests provides an aide-mémoire while 'the respondent has much latitude to respond to the questions in the ways that seem sensible to them'. In addition, both teachers and students completed a survey comprising a range of both open and closed questions.

It must be acknowledged that this is a small scale study, and may not represent the views of all Irish second-level students. However, in this case, there was an extensive demand from the majority of participants for more input into school processes. More research could help determine the extent of these views.

\section{Conceptual Framework}

The study is underpinned by values resembling the pillars supporting a Learning Organisation, which Taysum (2013) suggests are concerned with 'openness, 
attentiveness to the views of others, mutual respect and support', and identified by Rudduck and McIntyre (2007: 176) as:

(1) advocacy by institutional leaders

(2) enabling structures and practices

(3) a school culture that values and listens to all staff

(4) a culture of enquiry and research among teachers

(5) a tradition of pupil involvement in decision-making

\section{Research Ethics}

Prior to conducting the study permission was obtained from the principal and all participants, with parental consent for those under 18 years. All correspondence was accompanied by plain language statements of the purpose and conduct of the research. These ethical considerations helped in setting boundaries for a welldelimited scope as advised by Yin (1994). Ethical obligations were adhered to throughout, confirmed by obtaining sanction from Dublin City University (DCU).

\section{Findings}

\section{Students'Views}

Interviews (pseudonyms throughout):

It is recognised that having a voice increases the level of belongingness, activating engagement and improving motivation (Maslow, 1954). It also helps to address the feelings of disempowerment referred to by Lodge and Lynch (2002: 166), in their study of power in schools, in which they note 'young people in school 
perceive power principally as something that is exercised over them by adults (teachers and others in positions of authority)'. During his interview, John commented on the ways students have a say in decision-making in the school. He described three committees as: the Student Council (SC); Young Social Innovator (YSI); and Green Schools. It is necessary to be elected by the other students in the year onto the SC, and the elected student represents the other students for the year. He said 'that means you can directly put forward ideas for improving the school or different ways of doing things'. Being on the YSI committee was 'again ways of improving the school' and the Green Schools committee contributed to 'making the school more eco friendly and stuff like that'. John remarked that he was the chairperson of the latter committee. When asked what he found helpful in his own learning, he said 'I think it's just the teachers being more one-on-one with you ... like if you have a specific part that you don't understand the teacher will go slow over that'. He commented on being listened to and felt it was important to be able to speak to the teacher if he had any problems. When asked if he thought his learning connected with what he would like to do when he left school, he replied 'I don't know what I'm gonna do yet so it's kind of hard to know'. In his responses, John highlights skills he is learning that are inherent in school processes, such as debate, communication and taking personal initiative, valuing these, saying well, this year, especially in TY, you learn more about like talking to people and discussing different things and a kind of motivating yourself, more than having teachers just at you all the time. So I think that will help me in the future.

Asked if he thought he could use these skills and learning in any job, he continued to say 
yea, I think talking to the public and even when you are in working in an office, communicating with your boss and other co-workers can have a massive impact on how you perform and stuff like that so I think it's going to be a very important thing to do.

John also mentioned that he was the chairperson of Foroige, a communitybased youth organisation. This was as a result of the encouragement he received from his teacher. He said 'we were told to put ourselves forward for everything'.

Although he considered himself satisfied with his level of involvement in decisionmaking in the school, John said 'I think it would be better if we had a suggestion box around the school for people who didn't get onto the SC'. He thought he would be listened to if he asked for it. He said, 'they'd probably agree'. Although he has a voice, as an elected representative, John acknowledges the need for students in general to have their voice heard. His sentiment simultaneously reflects and promotes an advantage of a SC as outlined by Kehoe and Whyte (2005: 122) who conclude it can help to create a 'caring school environment which is supportive and inclusive'.

Jake and Ronan were interviewed together and they both mentioned the three committees that John had referred to. Jake spoke about a fun run his class had decided to organize and said it was a class decision. Both students reported being members of the Green Schools committee and they would like to be on the other two committees and held an intention to put themselves forward in the future. Jake talked about involvement in classroom decision-making, saying

every now and again the teacher would ask us more or less what, if there is anything, we'd like to cover. We more or less control what we learn; so if there are any particular topics we would like to get over and then we do that and when we're finished that we'd be asked again is there anything 
more. If we can't come up with something the teacher would come up with something for us.

Both students stated they 'got on well' with the teachers. Ronan said, 'we always listen to them and they listen to us, you know'. When asked what was important in their relationship, Jake spoke out about trust, remarking

definitely, there's trust and you build up respect for the teachers and they respect you. It's not good when you're not getting on with a teacher but it's usually. . . students tend to blame the teacher, but it's usually down to the student is doing something and it just annoys the teacher, but if you're doing your bit they will always meet you half way and you'll get on.

Looking at how their learning connected to what they would like to do when they left school, Jake spoke about work experience which he thought was very helpful. Ronan made the comment about their career guidance class 'which is just dedicated to us talking about what we will do in the future, help us get to doing it'. They also mentioned curriculum vitae preparation.

In relation to becoming more involved in decision-making in the school, Ronan remarked 'yea, I'd like to be on the SC, to be able to put my vote forward and what I think I can do. It would make me feel like I did something, leave my mark'.

Jake also said he wished to be elected onto it as well, saying 'so I can see where I could help improve the school run [fun run] and try and, you know, see if I could put any new rules into helping students behave and to slow down the bullying rate'. They both said students were encouraged to put themselves forward for it.

It was observed that the students interviewed held positions on one or more committees, and may not be representative of the class. However, it was open to the 
whole class to volunteer to participate in the interviews. The students who did volunteer may have done so because they are active in volunteering generally. A decision could have been made to request participants from students who had not volunteered, but as the spirit of the research was underpinned by democracy and voluntary participation it would have been inappropriate to exert such pressure.

\section{Student Survey Results}

\section{Open-ended questions:}

In order of frequency, Table 1 provides a summation of the themes from the student responses from the following open-ended questions:

- what ways would you like to get more or less involved in decision-making in your school?

- what is of most value to you about your involvement in school?

The students' responses have been categorised into themes, many appearing in responses to both questions.

\section{[Table 1 here]}

The greatest frequency (41) in the student replies related to wanting more of a say, more classroom discussions and an individual voice which was not just through representation with two students (one girl, one boy) elected from each year to the SC. It is interesting to note here that in particular the girls responded strongly, with this view being expressed by a total of 29 out of the 33 girls, compared with 11 out of the 27 boys. The second highest frequency (14) showed the value students placed in being on, or wished to be on, the SC or other committees. This result was more evenly spread between both girls and boys. Similar or linked themes which occurred 
in responses were the desire to have school leadership to consult students before decisions are taken (6 instances), wanting a voice in how and what is learned (4 instances), valuing having a voice (3 instances) and valuing or wishing to be respected (3 instances).

Different themes that emerged highlighted that students placed a value on socialising, including friendships (11 instances) and participation in sport ( 7 instances); they also showed how the students value education, as learning (9 instances) and education combined with socialisation, as being part of the school or wishing to participate more in school activities (6 instances).

The only other unrelated themes to occur related to pressure of the timetable and preparation for the Leaving Certificate examination (4 instances) and confidence, either valuing the confidence gained through school, or wanting to gain more selfconfidence (4 instances).

\section{Closed questions:}

Outlined in Table 2 below are the responses to the closed questions in the students' survey. Each chart shows the percentage of student responses for each category.

[Table 2 here]

Overall (Table 2, item 1), almost $40 \%$ of the students felt they were involved in decision-making at the school level sometimes, with a quarter each responding rarely or often. This was evenly distributed between the boys and girls.

In contrast, the most common answer from students was that they felt they were rarely involved in decision-making at the classroom level (item 2), with over a quarter 
each responding sometimes or often. Reflecting the responses to the open questions, this lack of involvement was felt most keenly by the girls, whilst the boys' responses were more evenly spread with a leaning to feeling they were often involved.

Questions in group three (item 3) dealt with issues of mutual trust and teachers knowing and liking students. The students were asked whether these factors helped with their learning. Almost half of students felt it helped them often, and another one in three said it nearly always helped.

The next group of questions (item 4) looked at respect between teachers and students, and fairness with peaceful conflict resolution within the classroom, and how these aspects helped with learning. Almost half of students felt it nearly always helped, and another $40 \%$ of students felt that it often helped. There was a slight difference between the boys' responses (most positive) and those of the girls who were more likely to answer often.

Answering questions about the relevance of learning opportunities in the school to what they would like to do when they leave school (in terms of education or a job) (item 5), the main responses fell to sometimes (37\%) with an even spread between often $(25 \%)$, and rarely $(28 \%)$.

\section{Teachers'Views}

It is important to say that some inexperienced teachers were satisfied to not be overly involved in the life of the school or in the decision-making process. For example, during the interview with Emma, who teaches French, she explained that, while she thought it was important to be involved, she was content with her level of participation, saying 
at the minute I'm happy where I am with the decision-making because ... I've only been teaching since February so at the minute I'm really concentrating on the classroom side of things until I find my feet more and get used to that side of things, but in the future I would like to be involved. I think it is important.

She mentioned that meeting with other teachers at the end of the day allowed her to voice her views or air any issues. She felt she would be welcomed on committees when she was ready to join and was confident she had a voice and it would be listened to. She commented 'we can go to management at any time ... viceprincipal or principal or a year head if it was to do with students'. Emma spoke of listening to more experienced teachers and management, mentioning that because she was new, she sometimes sought advice from the more experienced staff when making decisions. With this progressive support she pointed to the need to 'follow the course to get it [curriculum] done because you're preparing them [older students] for that specific exam' but felt that with younger classes there was more opportunity to 'do some cooking ... role plays about their family ... things that aren't necessarily sticking to the curriculum but it's more fun for them, more interactive for them'. When asked if she facilitated her students in decision-making processes in the classroom she explained 'I do try and involve them and I do try to take their opinions into consideration' but remarked at a later stage that

the way that the curriculum is at the minute you have to get a certain amount covered for the exam that they are doing at the end of it ... you might kind of go a bit off the point... I'm trying to focus on what they need to get done.

Mary, an experienced science teacher, feels very involved in school life and in the decision-making process. She reported teachers were 'asked their opinion and 
there is an empowerment in that'. Mary contributes to three committees and attends meetings regularly with school management and other staff. She recounted that she is 'chairperson of two and a participant in the third' and said she was satisfied with the level of decision-making and considered she was involved to her 'capacity'. She remarked that the principal and vice-principal were fully supportive of her efforts.

When asked if she facilitated her students in decision-making in the classroom, Mary initially responded with,

that's a difficult question because there are different levels of academia in the class. It's a mixed ability class and I'm not sure if the weaker student would be able to ... that they would have the capability of making the decision for the more academic student.

At a later point in the interview it was clear that there was a level of input by students into decision-making in the classroom when Mary commented students, 'especially in TY, the class would decide on ... classroom methodologies that we would use'. She believed that in TY there is 'more scope to develop the programme that suits the students'. In explaining her own involvement, Mary said

the more I got in different activities, the more the opportunities opened up for me to become more involved in the decision-making or I was bringing decisions that the students and some staff were making to management, just creating new opportunities.

\section{Teacher Survey Results}

In order of frequency, Table 3 provides a summation of the themes in the teacher responses from the following open-ended questions in the survey: 
- what ways would you like to get more or less involved in decision-making in your school?

- what is of most value to you about your involvement in school?

The teachers' responses have been categorised into themes.

[Table 3 here]

Although there is some overlap apparent in the teachers' responses, in answer to the first question emphasis is placed clearly on a desire for more meetings, discussions and two-way communication with the leadership (14 instances) and a dissatisfaction with the constraints caused by the dictates of the curriculum with no input (6 instances). The responses to the second question demonstrate that teachers value their role in teaching students and contributing to their development (12 instances). They also valued relationships (with both students and staff) and feeling appreciated (10 instances).

It is interesting that it is the more experienced teachers who reported that they valued, or wanted to feel, they were appreciated, while the less experienced teachers did not reflect this sentiment. It is also interesting that it was mostly or only inexperienced teachers who commented on the value of decision-making in the classroom and a preference for greater participation in the process of decision-making for nonpermanent, non-full-time teachers. It would appear that experienced teachers value being appreciated, while their less experienced colleagues wanted more tangible input, extending this wish to include part-time and non-permanent teachers.

Table 4 below illustrates the responses to the closed questions in the survey. Each chart shows the percentage of teacher responses for each category. 


\section{[Table 4 here]}

Overall, teachers indicated (Table 4, item 1) that they were sometimes involved in decision-making in their school. Experienced teachers regardless of position indicated that they were slightly more involved than the less experienced teachers.

At classroom level (item 2) teachers felt they were often or nearly always involved in decision-making. This could be expected because the teacher works semiautonomously in the classroom although working to a curriculum.

The next two sets of questions focused on what teachers find helpful in facilitating learning. The first set is on teachers' opportunities to interact with students and the esteem in which they hold them (item 3). The second is on teacher esteem in the classroom, how (teachers feel) students trust and respect the teacher and see them as fair (item 4). The responses show that overall at least two-thirds of teachers felt that learning is nearly always better if both teacher and students trust and respect each other, and a quarter felt it was often better.

Responding to questions on their students and learning opportunities (item 5), threequarters of the teachers believed that the opportunities sometimes or often relate to the students' real world.

In the questions on the curriculum and how it connects with the students' real world (item 6), almost half of the teachers reported it related to it sometimes, and a quarter of teachers rarely.

The questions on linking learning to what students already know include items about whether teachers talk to students about what they need to do and what qualifications 
they need to realise their hopes and dreams and to get the jobs they want; about what motivates them to learn; whether the teacher can respond to their learning needs; and whether the teachers feel motivated in their job (item 7). Slightly more than one in three teacher responses were sometimes and slightly less than that, often. In relation to the item on teacher motivation, the most common response given was nearly always.

In replying to the questions linking learning to teacher and student involvement in the community (item 8), there was a wide spread of responses. The most frequent answer (more than 40\%) was sometimes. A quarter of the teachers responses were rarely and another quarter often.

In response to the question of teachers' own learning and school support (item 9), there was a spread, with the main answer (over 40\%) given as sometimes teachers felt they had opportunity and support for their own professional development. One in four answered often and one in five rarely.

\section{Discussion}

In the teachers' case, the evidence shows that the level of input is curtailed by the teachers' need to satisfy curriculum stipulations. Morgan (2005) makes the point that young people still pass through an out-of-date educational system little changed from that experienced by preceding generations.

In the students' case, this same point is not without impact. Smyth (1999: 109) claims 'curricular packaging influences pupil stress levels within school' in relation to subject choice, and this 'may occur because students do not see the school as responsive to their particular needs or abilities'. Adding substance to this view O’Brien (2008) observes that well-being is negatively impacted by being denied a 
voice, which she notes applies to students who find themselves excluded from educational debate.

There is clear evidence from the findings that the teachers are committed to caring for the students entrusted to their care and value being in a position to help them in their development.

Teachers felt somewhat empowered overall by the leadership in the decision-making process, but expressed a need for all staff to become more involved (including nonpermanent and non full-time staff). They also expressed a wish for more discussions, meetings and reciprocal communication between staff and school leadership. Some inexperienced teachers felt less involved and less enabled to be involved in school processes than their more experienced colleagues. However, this is not necessarily as a result of exclusion. As Emma reported in her interview above, she was content as a new teacher with her level of participation until she felt more comfortable in her teaching role.

It is not surprising that the teachers appeared, on the whole, to be satisfied with the decision-making process at classroom level or that the majority of teachers found that learning is facilitated when there is mutual trust and respect between students and teacher. However, when it came to their students' learning, learning opportunities and the curriculum, the teachers' responses show that at best these only related to the students' real world some of the time.

Concerning the teachers' own learning and opportunities for continuing professional development, the evidence shows that they are less than satisfied, pointing to a lack of time as the main reason for this. It is heartening though that more than half of the teachers reported feeling motivated in their job most of the time. 
From the students' viewpoint, there is clear evidence from the overall findings to show that they feel that they have a measure of involvement in their school and classroom processes, though there is an eagerness to have greater involvement and more of a voice. They felt that they would like to be consulted, but not just on 'trivial' matters, and 'prior' to decisions being taken. As school leadership and practice impact their learning and progress, this need cannot be construed as an unreasonable expectation. Greater demand to have a student voice is becoming more commonplace, particularly with the advance of technology. Rogers (2002: 139) refers to an awareness of the blurring between pedagogical and andragogical practice and the division of influence, particularly when teaching with new technologies 'where children challenge authority, especially today when different learning methodologies and more self-directed exploratory processes are being encouraged ...'.

In an Irish context, this is also in line with the National Children's Strategy (2000: 30) which maintains a goal '.. to give children a voice in matters which affect them and to ensure that their views are given due weight in accordance with their age and maturity'. This goal is underscored by the value of children's need of 'help to learn responsibility as they grow towards adulthood and full citizenship' (p10). The Strategy also states that this goal 'recognises that children have an active contribution to make in shaping their own lives and the lives of those around them'. Providing a framework and supporting students in finding their voice meets one of the educational aims set out by the DES (1995: 12), 'to develop intellectual skills combined with a spirit of inquiry and the capacity to analyse issues critically and constructively'. However, this aim can only be achieved if students are proactively involved in all school processes, including decision-making. This is congruent with inclusive practice and cultural sensitivity where '... consultation with the aim of reaching 
consensus is the process which enables diversity to be accommodated' (Goddard and Leask, 1992: 9).

It could be said that students already have a voice through the SC, but this does not appear to go far enough in satisfying the need for representation as expressed by the majority of students in the findings. This has already been highlighted in the interview with John, a SC member, who called for a suggestion box to enable an input from students not elected as representatives. This finding is notwithstanding that students have more of an input into classroom learning methodologies and into the curriculum in TY than they would experience in other years.

Relationships with the teachers were important to students as issues of mutual respect and trust, which were seen to aid learning in responses to closed questions. These elements were also raised in open questions contained in the survey and in interviews. Trust in the teacher has been shown to be of primary importance when it comes to the self in the learning environment, because communication from those we trust has a relatively large effect on our self-concept (West and Turner, 2006). Relational aspects concerning students also included friendship with other students, and being involved in sporting and school activities, brought up in responses to open questions.

The relationship between the students' learning opportunities and their future, following school, was perceived to be less than optimal, although in the interviews students felt there was a positive relationship.

\section{Conclusion}

Evidence suggests that teachers and students in this school enjoy some influence and involvement in the decision-making processes and in the life of the 
classroom. It would also suggest that there is room, and a wish, for improvement. This is despite students and teachers working in the TY curriculum, within a more flexible framework than would be expected when undertaking the more formal aspects of the curriculum, such as the Leaving Certificate examination programme, where it is likely that students will have even less involvement.

In this Irish school, the principal appears progressive and was described as supportive of initiative and change by both experienced and inexperienced teachers in their interviews. This style of leadership is heading in the right direction, reflecting collegiality and a participative style of management (McGregor, 1960). However, the findings show that the teachers would welcome more involvement. Students are also seeking to have their voices heard and to become more involved in decisions that affect them in their life at school and beyond.

Noted already, it would be difficult to generalise the findings as the research was confined to one school. However, further research across a wider range of schools in different areas and contexts would be useful in demonstrating the generality or otherwise of these findings. Overall, there appears to be a call for more involvement by the majority of all participants, at least in this particular school.

This would suggest that, although there is a level of involvement by both teachers and students, the school needs to move forward by showing greater trust, displaying more openness and sharing whole school responsibility. These are constituents of a Learning Organisation where every individual contributes and is valued for their contribution. Although a worthy aim, this is not an easy ambition to achieve as outlined by the DES (2000: 127) which maintains that 'the challenge of transforming the workplace into a learning organisation is arguably the ultimate goal of a 
workplace strategy.' Nevertheless, to become agents of change, teachers and learners need to become interdependent, collaborative, critical thinkers. This will allow them to make 'better and more informed decisions about whether something is likely to be true, effective or productive' (Cottrell, 2005: 2). These metacognitive skills can be nurtured and honed by active involvement in the decision-making processes and the life of the school. Only in this way can teachers and learners be enabled to make an appreciable, worthwhile and sustainable difference to their individual and collective contributions to their school and their community during good and hard times. 


\section{References}

Aronson, E., Wilson, T. D. and Akert, R. M. (2005) Social Psychology. (5 ${ }^{\text {th }}$ Ed.) Upper Saddle River, NJ: Pearson Prentice Hall

Banks, J.A. (1997) Educating Citizens in a Multicultural Society. New York: Teachers College Press

Berg, B.L. (2004) Qualitative Research Methods for the Social Science (5 ${ }^{\text {th }}$ Ed.) Boston, MA: Pearson

Bhreathnach, N. (1995) Foreword. In Department of Education Charting our Education Future: White Paper on Education. Dublin: The Stationery Office

Bowne, B. P. (1908) Personalism: Common Sense, Science, and Philosophy. Boston, MA: Houghton Mifflin

Brown, S. (2005) How can research inform ideas of good practice in teaching? The contributions of some official initiatives in the UK. Cambridge Journal of Education 35, (3) 383-405

Bush, T. (2003) Theories of Educational Leadership and Management. ( $3^{\text {rd }}$ Ed.) London: Sage

Cottrell, S. (2005) Critical Thinking Skills: Developing Effective Analysis and Argument. Basingstoke: Palgrave Macmillan

Culturally Responsive Evaluation and Assessment (CREA) (2013) Conference Theme: 'Repositioning Culture in Evaluation and Assessment' [online]. Champaign, IL: College of Education, University of Illinois at Urbana Champaign. Available from: education.illinois.edu/crea/conference/theme [Accessed 10 ${ }^{\text {th }}$ April 2013]

Department of Education and Science (1994) Transition Year Programmes Guidelines for Schools [online]. Available from: www.education.ie/en/Schools-Colleges/Information/Curriculum-andSyllabus/Transition-Year-/ty_transition_year_school_guidelines.pdf [Accessed 01 August 2013] 
Department of Education and Science (1995) Charting our Education Future: White Paper on Education. Dublin: The Stationery Office

Department of Education and Science (2000) Learning for Life: White Paper on Adult Education. Dublin: The Stationery Office

Department of Education and Skills (2011) Statement of Strategy 2011 - 2014 [online]. Available from www.education.ie/en/Publications/CorporateReports/Strategy-Statement/des_strategy_statement_2011_2014.pdf [accessed $6^{\text {th }}$ August 2013]

Education Act. (1998) Dublin: Government Publications

EUDEC (2015) [online]. Available from: www.eudec.org/index.html [accessed $29^{\text {th }}$ May 2015]

Fisher, C. (2007) Researching and Writing a Dissertation: A Guidebook for Business Students. (2 ${ }^{\text {nd }}$ Ed.) Harlow: Pearson Education

Fox, M. (1993) Psychological Perspectives in Education. London: Cassell (Introduction to Education series)

French, G. (2007) Children's early learning and development - a background paper [online] Dublin: NCCA. Available from: www.ncca.ie/uploadedfiles/curriculum/ld background paper may.pdf [accessed $27^{\text {th }}$ September 2015]

Glaser, B. and Strauss, A. (1967) The Discovery of Grounded Theory. Chicago: Aldine

Goddard, D. and Leask, M. (1992) The Search for Quality: Planning for Improvement and Managing Change. London: Paul Chapman Publishing

Hanushek, E.A., Kain, J.F. and Rivkin, S.G. (1998) Teachers, Schools and Academic Achievement [online]. Working Paper 6691. Cambridge, MA: National Bureau of Economic Research. Available from www.nber.org/papers/w6691 [accessed $6^{\text {th }}$ June 2013]

Harley, K., Barasa, F., Bertram, C., Mattson, E. and Pillay, S. (2000) "The real and the ideal": teacher roles and competences in South African policy and practice. International Journal of Educational Development 20 (July 2000) 287-304 
Hebert, E.A. (2006) "The Boss of the Whole School”: Effective Leadership in Action. New York, NY: Teachers College Press

Husserl, E. (1931) Ideas Pertaining to a Pure Phenomenology and to a Phenomenological Philosophy. (Gibson, W.R.B. trans.) New York, NY: Collier Books (reprinted 1962) [Originally published London: Allen \& Unwin (1931) Translation of Ideen zu Einer Reinen Phänomenologie und phänomenologischen Philosophie (1913)]

Kehoe, A. F. and Whyte, J. (2005) Second Level Student Councils in Ireland: A Study of Enablers, Barriers and Supports. Dublin: The Children's Research Centre, Trinity College for the National Children's Office

Lave, J. and Wenger, E. (1991) Situated Learning: Legitimate Peripheral Participation. Cambridge: Cambridge University Press

Lodge, A. and Lynch, K. (2002) Equality and Power in Schools: Redistribution, Recognition and Representation. London: RoutledgeFalmer

Longworth, N. (1999) Making Lifelong Learning Work: Learning Cities for a Learning Century. London: Kogan Page

Loughran, J. (2006) Developing a Pedagogy of Teacher Education: Understanding Teaching and Learning about Teaching. Abingdon: Routledge

Maslow, A. (1954) Motivation and Personality. New York, NY: Harper and Row

McGregor, D. (1960) The Human Side of Enterprise. London: McGraw-Hill

McLean, A. (2003) The Motivated School. London: Paul Chapman Publishing

McNamara, G. and O'Hara, J. (2008) Trusting Schools and Teachers: Developing Educational Professionalism Through Self-Evaluation. Mahony, R. (ed.) Irish Studies, vol. 8. New York, NY: Peter Lang

Morgan, B. (2005) The Irish education system, private and public, is outdated and embarrassingly out of touch [online]. Available from: www.educationmatters.ie/2005/10/25/education-is-embarrassingly-out-oftouch/ [Accessed 04 August, 2013]

O'Brien, M. with the Human Development Team, St Patrick's College, Dublin (2008) Well-Being and Post-Primary Schooling: A Review of the Literature and 
Research. NCCA Research Report No. 6. Dublin: National Council for Curriculum and Assessment

O'Donoghue, T. and Harford, J. (2010) Troubling some generalisations on teacher education in the English-speaking world: the case of the Republic of Ireland. South African Journal of Education. 30 91-104

Ofsted (2013) Sands School [online]. Available from: reports.ofsted.gov.uk/index.php [accessed $04^{\text {th }}$ June 2015]

Paul, R. and Elder, L. (2006) Critical Thinking: Tools for Taking Charge of Your Learning and Your Life. ( ${ }^{\text {nd }}$ Ed.) Prentice-Hall: London

Rogers, A. (2002) Teaching Adults. ( $3^{\text {rd }}$ Ed.) Buckingham: Open University Press

Rudduck, J., and McIntyre, D. (2007) Improving Learning through Consulting Pupils. Oxon: Routledge.

Sands School (2015) [online]. Available from: www.sands-school.co.uk/aboutsands/democratic-education/ [accessed $5^{\text {th }}$ June 2015]

Senge, P.M. (2000) The Academy as Learning Community: Contradiction in Terms or Realizable Future? [online]. (Originally published as chapter twelve of Leading Academic Change: Essential Roles for Department Chairs, JosseyBass). Available from: www.aashe.org/documents/profdev/SengeThe_Academy_as_Learning_Community.pdf [Accessed 10 August 2013]

Sliwka, A. (2008) The Contribution of Alternative Education. In OECD Centre for Educational Research and Innovation (eds) Innovating to Learn, Learning to Innovate. [e-book, online]. OECD Publishing. Available from:

www.oecdbookshop.org/browse.asp?pid=titledetail\&lang $=\mathrm{en} \& \mathrm{ds}=\& \mathrm{k}=5 \mathrm{KZLG7JL9DKH}$

Smyth, E. (1999) Do Schools Differ? Academic and Personal Development among Pupils in the Second-Level Sector. Dublin: Oak Tree Press and the Economic and Social Research Institute

Submission to the National Strategy for Higher Education [online] (2009) National Council for Curriculum and Assessment (NCCA). Available from: www.ncca.ie/en/NCCA_submission_to_the_National_Strategy_for_Higher_E ducation.pdf [Accessed 28th July 2013] 
Sugrue, C. (2009) Back to the future: perspectives on current realities and future quality of educational research through the prism of Irish Educational Studies. Irish Educational Studies. 28 (1) 7-25

Taylor, B. (1998) Accountability: a practical guide. IN Teaching in Primary Schools. Cashdan, A. and Overall, L. (eds.) London: Cassell

Taysum, A. (2013) International boundary crossing study of teachers' and students' participation in institutional processes and practices; A pilot study of an English Case. Unpublished to be presented at ECER Conference September 2013, Istanbul

The National Children's Strategy: Our Children - Their Lives. (2000) Dublin: The Stationery Office

United Nations (1948) Universal Declaration of Human Rights [online]. Available from: www.un.org/en/documents/udhr/index.shtml\#a26 [accessed $11^{\text {th }}$ August 2013]

United Nations (1966) International Covenant on Economic, Social and Cultural Rights [online]. Available from: www.ohchr.org/EN/ProfessionalInterest/Pages/CESCR.aspx [accessed $11^{\text {th }}$ August 2013]

West, R. and Turner, L.H. (2006) Understanding Interpersonal Communication: Making Choices in Changing Times. Belmont, CA: Thomson Wadsworth Yin, R.K. (1994) 'Designing single- and multiple-case studies'. Chapter 10 in N. Bennett, R. Glatter, and R. Levačić (eds) Educational Management Through Research and Consultancy. London: Paul Chapman Publishing, in association with The Open University

Zhang, Y. (2011) Principals' and Teachers' Perceptions of Their Role and Interaction Under Current Chinese Reform: A Case Study in Shandong Province PhD Thesis, Queensland University of Technology 
Table 1

\begin{tabular}{|c|c|c|c|}
\hline \multicolumn{3}{|c|}{ Number } & \multirow{2}{*}{ Theme } \\
\hline $\mathrm{F}$ & M & Total & \\
\hline 29 & 11 & $41 *$ & $\begin{array}{l}\text { More say, class discussions, vote, not just Student Council (SC) } \\
\text { representation, make a difference }\end{array}$ \\
\hline 6 & 7 & $14^{*}$ & $\begin{array}{l}\text { Would like to be on or value being on SC or other committee(s) and } \\
\text { would like more discussion with management, more feedback, on } \\
\text { important (not just trivial) issues }\end{array}$ \\
\hline 6 & 5 & 11 & Having, making friends, getting to know new people \\
\hline 5 & 4 & 9 & Value learning, class \\
\hline 4 & 3 & 7 & Value playing sport \\
\hline 3 & 2 & $6^{*}$ & $\begin{array}{l}\text { Value or would like more involvement in school activities, being part of } \\
\text { the school }\end{array}$ \\
\hline 4 & 2 & 6 & Consultation, involvement in discussion, before decisions are taken \\
\hline 2 & 2 & 4 & Want voice in what and how we learn \\
\hline 1 & 3 & 4 & $\begin{array}{l}\text { Value working for, have no want/time for involvement because of, } \\
\text { Leaving Certificate/timetable }\end{array}$ \\
\hline 4 & & 4 & $\begin{array}{l}\text { Confidence issues, want OR value gaining (don't speak/want to speak } \\
\text { because...) }\end{array}$ \\
\hline 3 & & 3 & Having a voice; being listened, paid attention to \\
\hline 2 & 1 & 3 & Students should be shown more respect; value being respected \\
\hline
\end{tabular}

The teachers' responses have been categorised into themes: 
Table 2

\begin{tabular}{|c|c|c|c|}
\hline \multicolumn{3}{|c|}{ No } & \multirow[t]{2}{*}{ Theme } \\
\hline$<10 \mathrm{yrs}$ & $>10 \mathrm{yrs}$ & Total & \\
\hline 3 & 9 & 12 & $\begin{array}{l}\text { Value students, teaching them and helping in their } \\
\text { development }\end{array}$ \\
\hline 2 & 8 & 10 & Prefer more meetings and discussions \\
\hline 2 & 4 & 6 & $\begin{array}{l}\text { Value relationships and mutual respect with } \\
\text { students and staff }\end{array}$ \\
\hline 1 & 5 & 6 & $\begin{array}{l}\text { Curriculum inflicts top-down approach, undue time } \\
\text { constraints, restricts input and decision making }\end{array}$ \\
\hline- & 4 & 4 & $\begin{array}{l}\text { Need to feel valued or they value feeling valued or } \\
\text { appreciated }\end{array}$ \\
\hline 1 & 3 & 4 & $\begin{array}{l}\text { There is a need for communication and reciprocal } \\
\text { feedback to from the leadership }\end{array}$ \\
\hline 2 & 1 & 3 & $\begin{array}{l}\text { Find it difficult being new/other staff cannot talk } \\
\text { freely in the presence of new staff }\end{array}$ \\
\hline 2 & 1 & 3 & $\begin{array}{l}\text { Value participating in decision making in the } \\
\text { classroom }\end{array}$ \\
\hline 2 & - & 2 & $\begin{array}{l}\text { Prefer more involvement in decision making for } \\
\text { non-permanent/non full-time staff }\end{array}$ \\
\hline
\end{tabular}




\begin{tabular}{|c|c|c|l|}
\hline \multicolumn{2}{|c|}{ No } & \\
\hline$<10 y r s$ & $>10 y r s$ & Total & \\
\hline- & 2 & 2 & Need more time in general and for input into \\
training and for continuous professional \\
development (CPD)
\end{tabular}

Table 3: Teachers and Students Engage with Different Participatory Processes

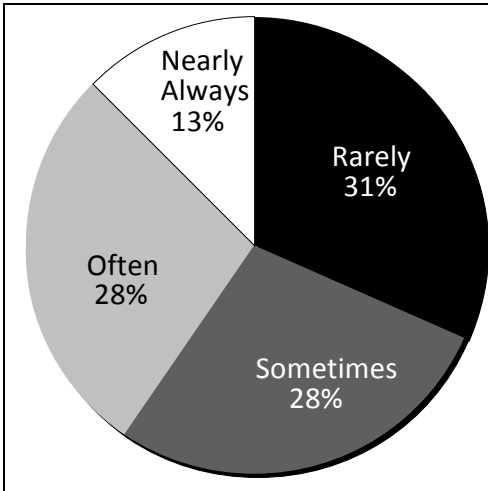

How involved students feel in decision making at classroom level:

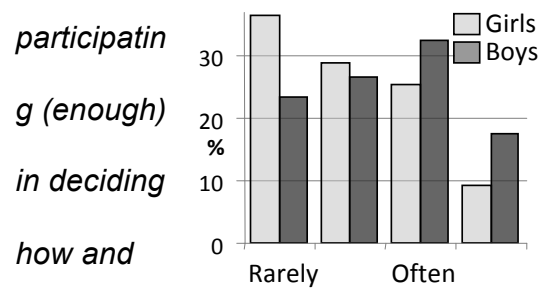

what is learned; and how the learning affects job prospects

following school and participation in groups outside school.

A small majority overall feel they are "rarely" or "sometimes" involved (59\%) - most girls (37\%) feel "rarely" involved, whereas most boys (32\%) feel "often" involved. 


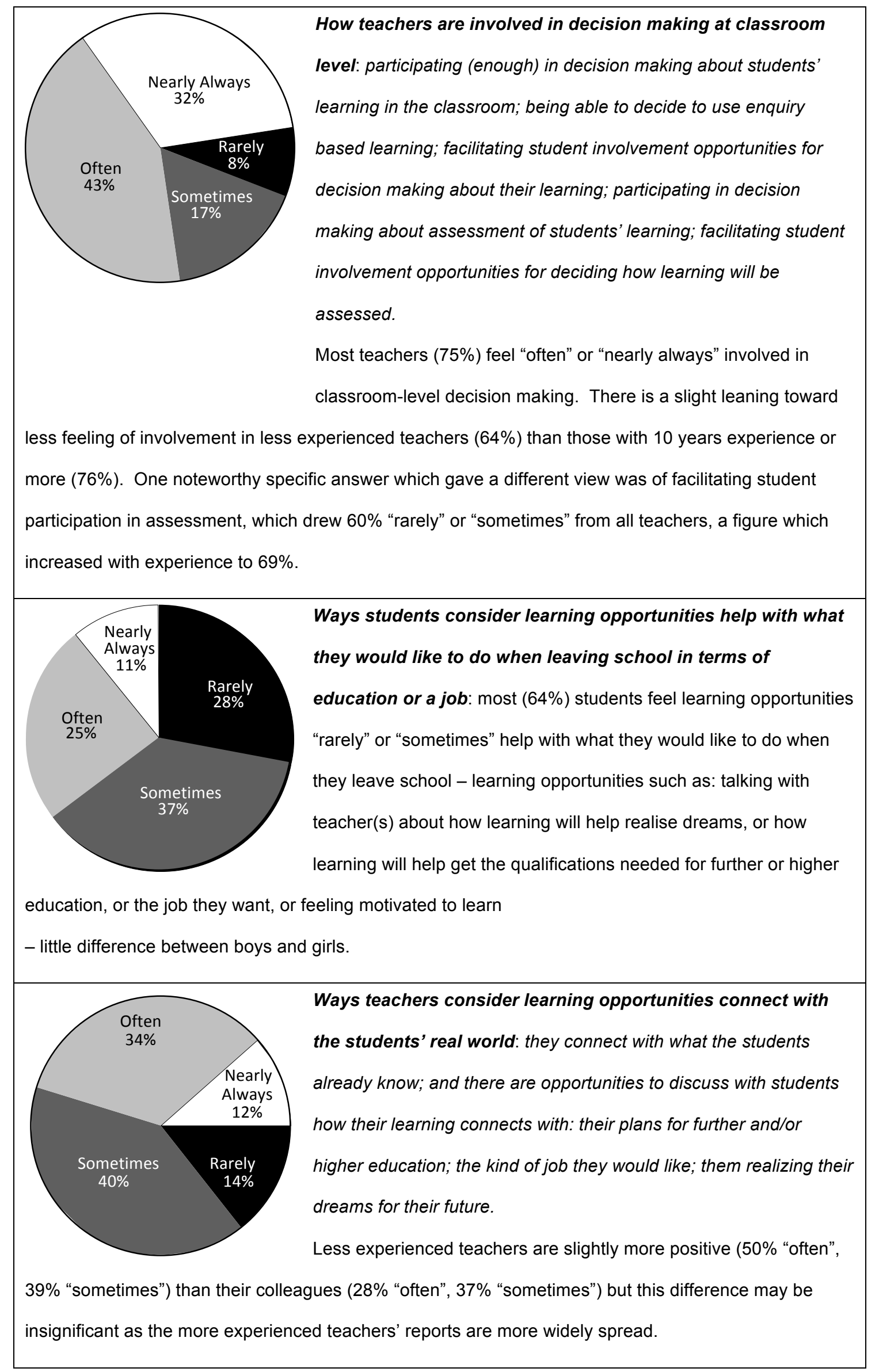


Table 4: School Characteristics: Institutional Stakeholders Place Value In:

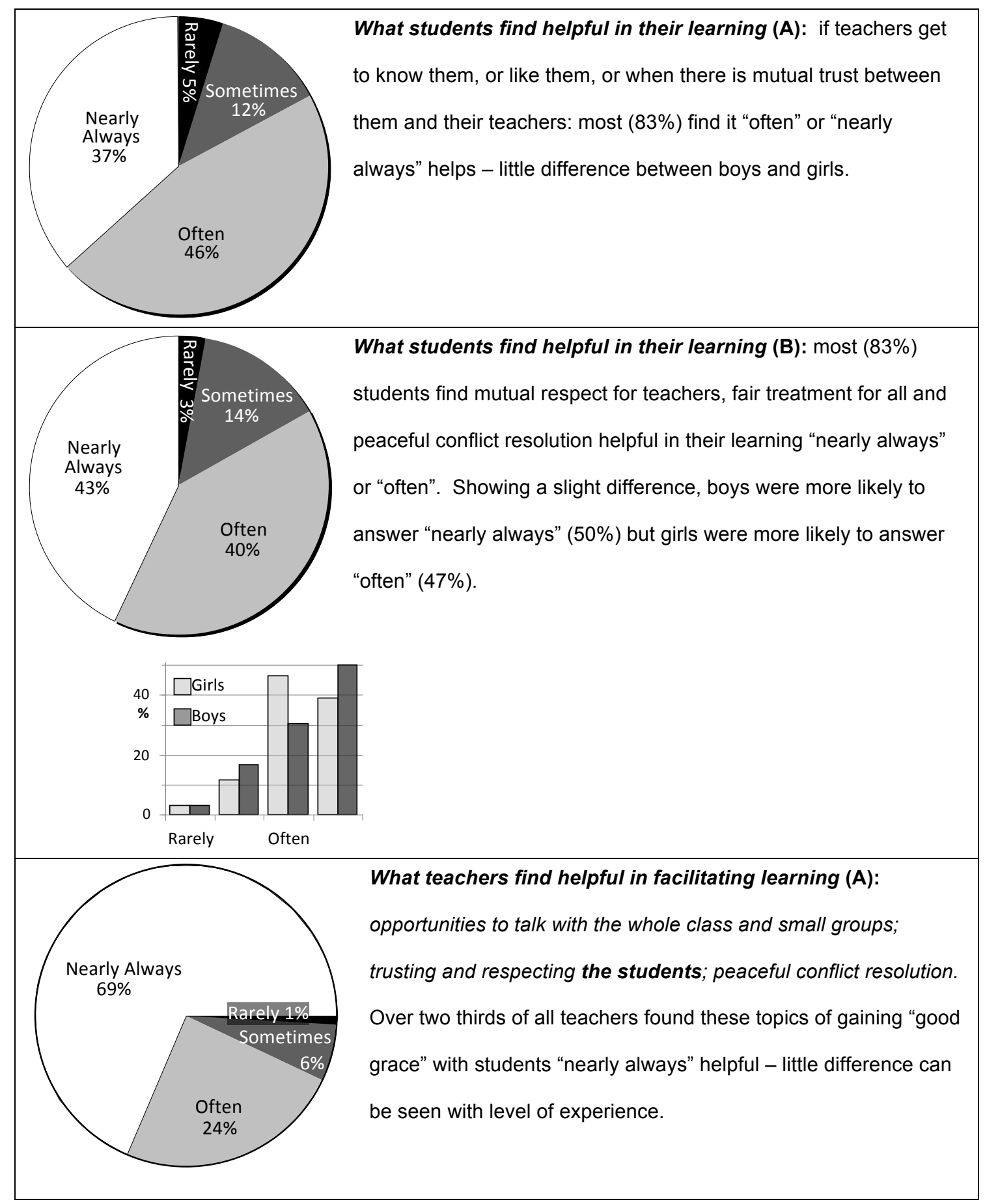




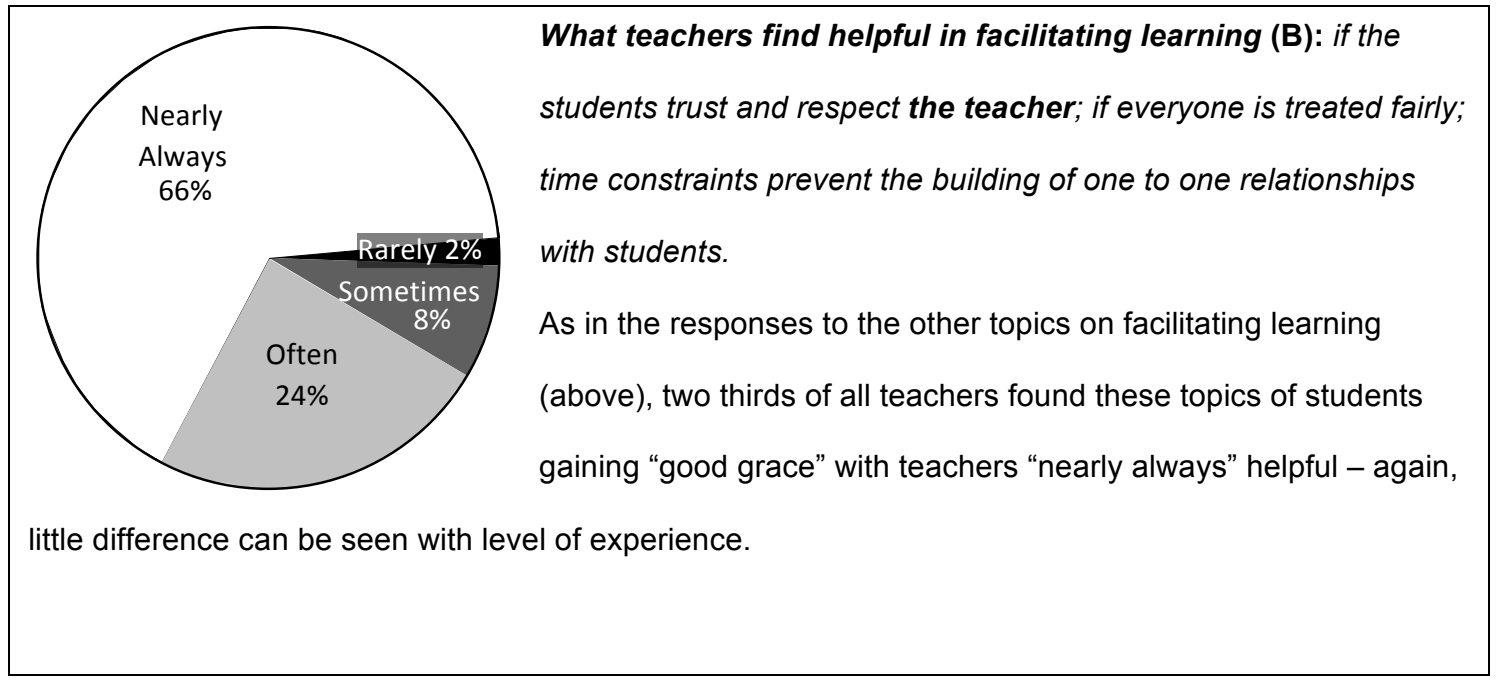

Table 5: Cultures, Practices and Leadership Systems that Influence Participation

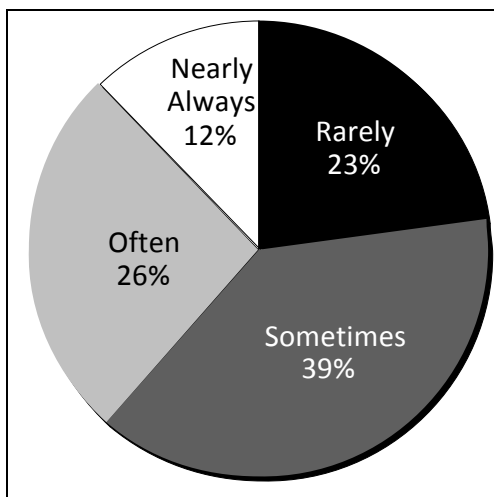

How involved students feel in decision making at school level:

knowing roles and responsibilities available for involvement in

decision making; participating in decision making; participating

enough in decision making; having opportunities to contribute to

decision making; having opportunities to contribute to decision

making about possibilities in school.

A small majority feel they are "rarely" or "sometimes" involved (62\%)

- little difference between boys and girls. 


How teachers get involved in decision making at school
level: knowing roles and responsibilities available for
involvement in decision making; participating in decision making;
contributing enough to decision making; having opportunities to
contribute to decision making; having opportunities to contribute
to decision making about possibilities in school.
Elways
Experienced teachers (10+ years, number of teachers $=17$ ) felt
most involved "sometimes" or "often" (73\%), whilst those less
experienced (less than 10 years, number of teachers = 7) felt
mostly (62\%) they were involved "sometimes"; the difference with
"sometimes".

